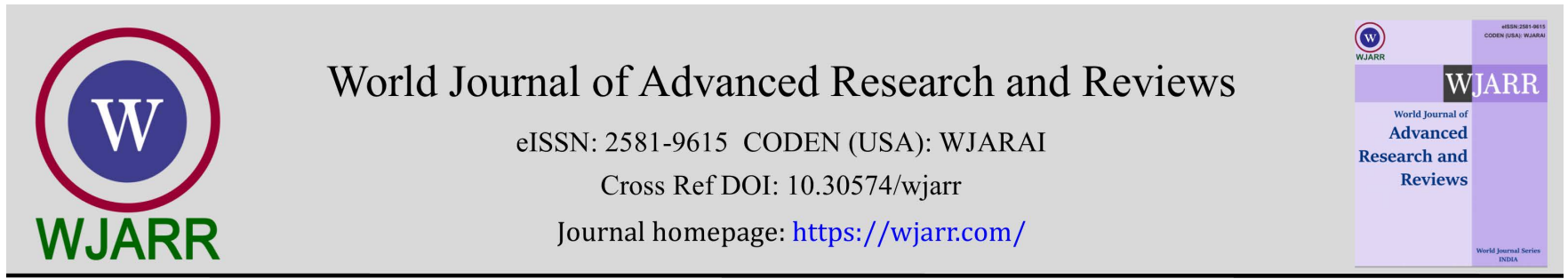

(RESEARCH ARTiClE)

\title{
Heavy metal and water quality at settling ponds of a post-mining area after reclamation and revegetation at Cibadak Sukabumi, Indonesia
}

\author{
Muhammad Mujahid 1, Iis Diatin 2,* and Juang Rata Matangaran ${ }^{3}$ \\ ${ }^{1}$ Department of Fisheries Resources Utilization Graduate School of IPB University, Bogor, Indonesia. \\ 2 Department of Aquaculture, Faculty of Fisheries and Marine Science, IPB University, Bogor, Indonesia. \\ 3 Department of Forest Management, Faculty of Forestry, IPB University, Bogor, Indonesia.
}

World Journal of Advanced Research and Reviews, 2021, 12(03), 624-628

Publication history: Received on 26 November 2021; revised on 29 December 2021; accepted on 31 December 2021

Article DOI: https://doi.org/10.30574/wjarr.2021.12.3.0748

\begin{abstract}
We analyzed the heavy metals and water quality of a post-mining area of silica for material of cement factory. The research was located in the Cibadak district, Sukabumi West Java Indonesia. The water sampling method was carried out in two locations, namely a large settling pond and a small settling pond. Water quality parameters were analyzed such as $\mathrm{pH}$, alkalinity, turbidity, total organic matter, and total ammonia nitrogen. The results showed that the water in both pond contents heavy metals. The heavy metals in the form were Mercury ( $\mathrm{Hg})$, Cadmium (Cd), Copper (Cu), Lead $(\mathrm{Pb})$, Arsen (As), Ferrum (Fe), and Cromium (Cr6+) in the both settling ponds. However, in small pond s there was a higher Fe value so the water is yellowish. There is a difference in acidity showed in the two ponds, $\mathrm{pH} \mathrm{3-4} \mathrm{in} \mathrm{the} \mathrm{small}$ pond and the large pond pH 7-8. Total organic matter was higher in large pond. Small settling pond has a very low pH value, so they are classified as acidic waters and contain high iron content so they cannot be used for human needs or aquatic life. Large settling ponds can still be used for aquaculture activities.
\end{abstract}

Keywords: Settling-pond; Water quality; Heavy metal; Post-mining area

\section{Introduction}

Open pit mining is a mining activity that is generally carried out above the surface. Mining begun after excavation of soil and rocks that cover mineral content. Open pit mining activities usually use heavy equipment to excavate soil and rock on top of the mineral, and then a dredging machine will extract the minerals. Open pit mining causes acid mine drainage and changes in water quality in and around the mine area. This water occurs due to the influence of natural oxidation of sulfide minerals contained in exposed rocks during mining. This process produces water that has a low $\mathrm{pH}$ which has the potential to dissolve heavy metals from the rock.

The acid mine drainage usually flow through to the settling pond. At the mining area settling pond is made which functions to accommodate acid mine water formed as a result of open-pit mining. Ponds can also be used for various purposes other than water can also be used for fish farming. The life of aquatic communities is influenced by the quality of the aquatic environment. Water quality parameters that have a major influence on the life of aquatic biota are physical and chemical factors. In addition to these factors, heavy metal content can reduce water quality and pollute the environment. Water becomes toxic for aquatic organism [1]. Open pit mining can change the water quality and quantity of the water. Some research showed that settling pond can be used for fish farming [2] [3]. This research was conducted to measure the heavy metal and water quality of two settling ponds at a post-mining area.

\footnotetext{
* Corresponding author: Iis Diatin

Department of Aquaculture, Faculty of Fisheries and Marine Science, IPB University, Bogor, Indonesia.

Copyright (C) 2021 Author(s) retain the copyright of this article. This article is published under the terms of the Creative Commons Attribution Liscense 4.0.
} 


\section{Methods}

\subsection{Location}

The research was conducted at settling pond of a post-mining area. One of the silica quarries manage by a company located in Cibadak Sukabumi West Java Indonesia with an area approximately 70 hectares. There were two settling ponds located in the ex-silica mining area. The small settling pond is about 0.1 hectare (small) and the large settling pond about 0.5 hectare (large).

\subsection{Revegetation}

The area around the settling have been revegetated with some trees. Data of the species and number of trees were planted collected from the mining office. The company tried to restoring the ecosystem through reclamation and revegetation. The area was designed to become a plantation forest. After three years planting 38,900 trees have been grown with dominated by Pinus merkusii tree species, and another tree species also growing well were Gmelina (Gmelina arborea), Trembesi (Samanea saman), and Puspa (Schima wallichii).

\subsection{Water quality and heavy metal measurement}

The parameter of water quality such as water temperature, pH, alkalinity, Total Ammonia Nitrogen (TAN), turbidity and Total Organic Matter (TOM) were measured. The water temperature was measured using thermometer, pH were measured using pH meter. Alkalinity, TAN, turbidity and TOM were measured using spectrophotometer regarding to method establish by APHA [4]. Heavy metal was measured using Atomic Absorption Spectroscopy (SSA) method.

\section{Results and discussion}

\subsection{Water quality}

Table 1 The water quality in both settling pond of post-mining area

\begin{tabular}{|l|l|c|c|}
\hline No & Parameter of water quality & Settling pond (large) & Settling pond (small) \\
\hline 1 & $\mathrm{pH}$ & $7.5-8.0$ & $3.5-3.7$ \\
\hline 2 & Alkalinity (mg/L) & 54.14 & 0 \\
\hline 3 & Total Ammonia Nitrogen/ TAN (mg/L) & 0.025 & 0.023 \\
\hline 4 & Turbidity (NTU) & 4.0 & 27.0 \\
\hline 5 & Total organic matter /TOM (mg/L) & 8.66 & 24.55 \\
\hline
\end{tabular}

Acidity or $\mathrm{pH}$ of water at the large settling pond was $7.5-8.0$, and the small setting pond was 3.5-3.7. The small settling pond was very acid water compare with the large settling pond. Acidity or $\mathrm{pH}$ is the result of measuring the activity of hydrogen ions in water which shows the balance between acid and base. According to [5] $\mathrm{pH}$ is closely related to the alkalinity content, the higher the pH value, the higher the alkalinity value. At a pH less than 5 the alkalinity may go undetected. The toxicity of chemical compounds is also affected by $\mathrm{pH}$. The normal pH value of a lake is 6-9. Natural fresh water is in the 4-9 range. Surface water in general tends to be alkaline, while ground water is more acidic. The maximum water $\mathrm{pH}$ range for fish production is 6.5 to 9 [6] The quality standard for drinking water is in the range of 69 [7] while the $\mathrm{pH}$ of the water consumed is in the range of $7-8.5$. If we drink water with a pH below 6.5 , it means the water is acidic, this is not good for the human body. The degree of acidity $(\mathrm{pH})$ ideal or normal for humans is 7-7.4. The human body is slightly alkaline, so with an ideal $\mathrm{pH}$ the body will be stronger in resisting disease, so the human body should be more alkaline than acidic. If the $\mathrm{pH}$ is below 7 it is very dangerous because the body cannot tolerate an acid imbalance for a long time, meaning that there is a buildup of carbon dioxide in the blood. Some of the symptoms that usually occur if our blood is acidic, namely indigestion, fatigue, joint pain. High carbon dioxide will make breathing difficult. The $\mathrm{pH}$ value of small settling ponds is very acidic so that it cannot be used for human needs and aquatic biota life.

Alkalinity is a description of the capacity of water to neutralize acids, usually defined as the amount of base present in the water, so it is also called the buffering capacity of changes in the $\mathrm{pH}$ of the waters. Alkalinity plays a role in 
determining the ability of water to support the growth of algae and other aquatic life, this is due to the influence of the buffer system of alkalinity, so that alkalinity is an indication of water fertility. Very low pH values (acidic) in small settling ponds, resulting in zero or undetectable alkalinity values (Table 1), while in large settling ponds the alkalinity range is quite good for aquatic biota life. Alkalinity for fish farming is more than $20 \mathrm{mg} / \mathrm{L}$ [8], if it is less than $20 \mathrm{mg} / \mathrm{L}$ the fish will be stressed [9], good alkalinity for fish is around $50 \mathrm{mg} / \mathrm{L} \mathrm{[10].}$

Nitrogen is the main nutrient that affects water productivity. Natural sources of nitrogen come from rainwater (precipitation), nitrogen fixation from water and sediments, and run-off from land and groundwater [11]. TAN concentrations above $2 \mathrm{mg} / \mathrm{L}$ cause ammonia levels that are potentially harmful to aquatic biota when the pH is above 8 [10] [12]. The value of TAN (Table1) of both settling ponds were below $2 \mathrm{mg} / \mathrm{L}$, it means the TAN were safe for aquatic biota.

Turbidity at large settling pond was 4.0 NTU, it means the water can be used for fish farming and as drink water. At the small settling-pond the turbidity was 27.0 NTU, it means the water can be used only for fish farming [13]. Turbidity is caused by the presence of suspended and dissolved organic and inorganic materials such as mud and fine sand, as well as inorganic and organic materials in the form of plankton and other microorganisms [4]. The smaller or lower the level of turbidity of a water, the deeper the light can enter the water body and the greater the opportunity for aquatic vegetation to carry out the photosynthesis process, the greater the supply of oxygen in the water. The turbidity value produced in this study can be tolerated for aquatic life, but cannot be used for drinking water, because the quality standard requirements for drinking water are below 5 (PRRI 2001). Good turbidity concentrations for fish farming range from 25-50 NTU [14] or less than $20 \mathrm{mg} / \mathrm{L}$ [8] and range from 30-80 NTU [9].

Total Organic Matter (TOM) of the large settling pond was $8.66 \mathrm{mg} / \mathrm{L}$ and the small settling pond was $24.55 \mathrm{mg} / \mathrm{L}$. Both ponds showed that TOM still under the value $400 \mathrm{mg} / \mathrm{L}$, it means the water can be used for aquatic biota. Sources of organic matter in waters come from external and internal. Internal organic matter comes from the waters itself, while external can be in the form of surface run-off, from the atmosphere, domestic waste and agricultural activities. Organic matter in aquatic ecosystems is in the form of dissolved organic compounds to particulate organic matter in large aggregates as well as from dead living organisms. Only a small amount of dissolved organic matter is directly used by aquatic organisms, while the particulate form is the main food source. Decomposition of dissolved organic matter produces final products in the form of gas and particulate organic matter which must be converted enzymatically by certain microbes [11] so as not to disturb the waters. The value of organic matter content in settling ponds is still at the tolerance threshold for aquatic life, which is below $400 \mathrm{mg} / \mathrm{L}$ [7].

\subsection{The heavy metal}

Metals are natural elements obtained from the sea, rock erosion, mining, volcanism and other industries. One of the main sources of heavy metal income comes from mining activities. According to [15] the nature of heavy metal toxicity can be grouped into 3 (three), namely; highly toxic consisting of elements $\mathrm{Hg}, \mathrm{Cd}, \mathrm{Pb}$, $\mathrm{Cu}$ and $\mathrm{Zn}$; medium toxic consisting of $\mathrm{Cr}, \mathrm{Ni}$ and $\mathrm{Co}$; and is very low toxic consisting of $\mathrm{Mn}$ and Fe. Heavy metals are dangerous elements, so heavy metal contamination in the environment causes toxicity to soil, air and water to increase. Heavy metals that often pollute waters are $\mathrm{Hg}, \mathrm{Cr}, \mathrm{Cd}$, as and $\mathrm{Pb}$. Heavy metals that are toxic in water are $\mathrm{Hg}, \mathrm{Cd}$ and $\mathrm{Pb}$ and the most toxic in waters are As, Ba, Cd, Cr, Hg, Se and [16]. The concentration of heavy metals in sediments and waters should not exceed quality standards, because they have an impact on humans who consume them.

Table 2 Heavy metal in the water of settling pond

\begin{tabular}{|l|l|c|c|}
\hline No & Heavy metal & Settling pond (large) & Settling pond (small) \\
\hline 1 & $\mathrm{Hg}(\mathrm{mg} / \mathrm{L})$ & $<0.001$ & $<0.001$ \\
\hline 2 & $\mathrm{Cd}(\mathrm{mg} / \mathrm{L})$ & $<0.001$ & $<0.001$ \\
\hline 3 & $\mathrm{Cu}(\mathrm{mg} / \mathrm{L})$ & $<0.001$ & $<0.001$ \\
\hline 4 & $\mathrm{~Pb}(\mathrm{mg} / \mathrm{L})$ & $<0.001$ & $<0.001$ \\
\hline 5 & $\mathrm{As}(\mathrm{mg} / \mathrm{L})$ & $<0.001$ & $<0.001$ \\
\hline 6 & $\mathrm{Cr} 6+(\mathrm{mg} / \mathrm{L})$ & $<0.001$ & $<0.001$ \\
\hline 7 & $\mathrm{Fe}(\mathrm{mg} / \mathrm{L})$ & 0.071 & 2.213 \\
\hline
\end{tabular}


In the Table 2 showed that all heavy metal was very small concentrate except the Fe. The Fe showed $0.071 \mathrm{mg} / \mathrm{L}$ of the water at large settling pond and 2.213 for the water at small settling pond. This Fe has to be considered because it is dangerous for human and aquatic biota.

Metals are natural elements obtained from the sea, rock erosion, mining, volcanism and other industries. One of the main sources of heavy metal income comes from mining activities. According to [15], the nature of heavy metal toxicity can be grouped into 3 (three), namely; highly toxic consisting of elements $\mathrm{Hg}, \mathrm{Cd}, \mathrm{Pb}, \mathrm{Cu}$ and $\mathrm{Zn}$; medium toxic consisting of $\mathrm{Cr}$, Ni and Co; and is very low toxic consisting of $\mathrm{Mn}$ and Fe. Heavy metals are dangerous elements, so heavy metal contamination in the environment causes toxicity to soil, air and water to increase. Heavy metals that often pollute waters are $\mathrm{Hg}, \mathrm{Cr}, \mathrm{Cd}$, as and $\mathrm{Pb}$. Heavy metals that are toxic in water are $\mathrm{Hg}, \mathrm{Cd}$ and $\mathrm{Pb}$ and the most toxic in waters are $\mathrm{As}, \mathrm{Ba}, \mathrm{Cd}, \mathrm{Cr}, \mathrm{Hg}$, Se and Ag [16]. The concentration of heavy metals in sediments and waters should not exceed quality standards, because they have an impact on humans who consume them.

In animals, humans and plants, iron metal ( $\mathrm{Fe})$ is essential, less stable and slowly turns into ferrous $\left(\mathrm{Fe}^{2+}\right)$ or ferric $\left(\mathrm{Fe}^{3+}\right)$. In natural waters with a $\mathrm{pH}$ of about 7 and sufficient dissolved oxygen levels, ferrous ions which are easily soluble are oxidized to ferric ions. At a $\mathrm{pH}$ of 7.5-7.7 ferric ions are oxidized and bind to hydroxides to form $\mathrm{Fe}(\mathrm{OH})_{3} \mathrm{which}$ is insoluble and settles to the bottom of the water forming a reddish color on the bottom substrate. So that iron is found in water with anaerobic conditions and acidic conditions. The toxicity of iron to fish ranges from $0.3-10 \mathrm{mg} / \mathrm{L}$. Therefore, iron is only found in waters under anaerobic (anoxic) and acidic conditions [11]. Iron content in natural waters ranges from $0.05-0.2 \mathrm{mg} / \mathrm{L}$ [6]. Iron content $>1.0 \mathrm{mg} / \mathrm{L}$ is considered dangerous for aquatic organisms. Water intended for drinking water should have an iron content of less than $0.3 \mathrm{mg} / 1$ and water intended for agricultural purposes should have an iron content of no more than $20 \mathrm{mg} / \mathrm{L}$ [17]. The lethal concentration (death) for fish ranged from 0.3-10 mg/L. The quality standard for clean water, the permitted level of iron (Fe) for drinking water is $0.3 \mathrm{mg} / \mathrm{L}$ [7]. The results of the study show that small settling ponds contain high levels of iron that are quite high and dangerous, this is marked by yellowish red water, so it cannot be used for the needs of humans and aquatic biota.

\section{Conclusion}

Small settling pond has a very low pH value, so they are classified as acidic waters and contain high iron content so they cannot be used for human needs or aquatic life. Large settling ponds can still be used for aquaculture activities.

\section{Compliance with ethical standards}

\section{Acknowledgments}

We thank to Mr. Upar the staff of forest revegetation and land reclamation of the post-mining area for the permission to conduct the research and the data collection.

\section{Disclosure of conflict of interest}

The authors declare that there is no conflict of interest regarding the main research, authorship and publication of this paper.

\section{References}

[1] Simate GS, Ndlovu S. Acid mine drainage: Challenges and opportunities. Journal of Environmental Chemical Engineering. 2014; 2: 1785-1803.

[2] Bidayani E. Aquaculture analisys of Patin (Pangasius pangasius) and Dumbo catfish (Clarias gariepinus) substitute result the formulated meals (pellets) with chicken guts, in Kolong (the lakes of tin mining activity). Akuatik. 2007; 1(1): 21-26.

[3] Pagoray H, Ghitarina. Characteristic of water quality of coal post-mining pool which used for fish cultivation. Ziraa'ah. 2016; 41(2): 276-284.

[4] APHA (American Public Health Association). Standard Methods for Examination of Water and Wastewater. 17th edition. Washington DC. 1989.

[5] Mackereth FJH, Heron J, Talling JF. Water Analysis. Fresh Water Biological Assocoation. UK. 1989. 
[6] Boyd C. Water Quality. In: Lucas JS and Southgate PC, editor. Aquaculture: Farming Aquatic Animals and Plants. Second edition. US. Willey-Blackwell. 2012.

[7] PRRI (Peraturan Pemerintah Republik Indonesia) No 82 Tahun 2001. About water quality management and water pollution control. Secretary of State of the Republic of Indonesia. Jakarta. 2001.

[8] Wedemeyer GA. Physiology of fish in intensive culture systems, New York, Chapman \& Hall. 1996.

[9] Bhatnagar A. Devi Water quality guidelines for the management of pond fish culture. International Journal of Environmental Sciences. 2013; 3(6): 1980-2009.

[10] Boyd C. Nitrification important process in aquaculture. Global Aquaculture Advocate. 2007; 10(3): 64-66.

[11] Cole GA. Texbook of Limnology. 3 rd edition. Waveland Press Inc Illinois. USA. 1988.

[12] Boyd CE. Nitrogen limiting factor in aquaculture production. Global Aquaculture Advocate. 2008; 11(2): 6162.

[13] Diatin I, Mujahid M, Teduh A, Matangaran JR. Ornamental carp fish cultured in settling pond after revegetation of ex-silica mining area. Pertanika Journal of Tropical Agricultural Science. 2018; 41(3): 10711084.

[14] Boyd CE. Particulate Matter, Color, Turbidity, and Light. In: Water Quality. Springer, Cham. 2015.

[15] Palar H. Heavy Metal Pollution and Toxicology. Rineke Cipta. Jakarta. 2004.

[16] Davis ML, Cornwell DA. Introduction Environmental Engineering. Second Edition. McGraw Hill Inc. New York. 1991.

[17] Moore JW. Inorganics Contaminants of Surface Water. Springer-Verlag. New York. 1991. 